\title{
Revitalisasi Ilmu Dakwah: Kajian Mabadi ‘Asrah Ilmu Dakwah
}

\author{
Tata Sukayat \\ UIN Sunan Gunung Djati Bandung \\ E-mail: sukayat02@yahoo.com
}

\begin{abstract}
Although dakwah activities have been crossed such a long history, but dakwah as a science is still relatively new. Moreover, the study area is almost tangent to the dakwah as a science with some other existing knowledge and have been developed more earlier, dakwah science have been so important for us to develop in more powerful, which in turn can generate a deeper motivation to develop it. Despite much research on the revitalization of the science mission with a diverse range of perspectives, but this paper will look at the process of revitalizing the science of dakwah in perspective mabadi 'asrah which has been well-known in the Islamic sciences tradition that are expected to be more independent as well as seeking the position and its relationship with other sciences which has been exist before.
\end{abstract}

\section{Kata Kunci:}

Revitalisasi, Mabadi ‘Asrah, Ilmu Dakwah

\section{A. Pendahuluan}

Penataan revitalisasi ilmu dilakukan terhadap seluruh ilmu yang dikelola, termasuk di dalamnya ilmu dakwah. Terlebih ilmu dakwah dipandang masih berusia sangat muda yang masih mencari identitas diri. Ilmu dakwah akan mudah dibentuk dan dikembangkan apabila diimbangi oleh landasan ontologis dan epistemologis yang kuat dan terarah. Namun bila tidak, ia akan kehilangan identitas dirinya. Bahkan akan menjadi bagian dari "pohon lain": ilmu komunikasi (komunikasi dakwah), atau tergelincir menjadi "fiqh dakwah". 
Salah satu langkah penting dilakukan dalam merevitalisasi ilmu dakwah adalah menelusuri terlebih dahulu landasan ilmiah yang mungkin dapat dibangun. Ini dilakukan terutama untuk menentukan kerangka pemikiran yang jelas dalam merumuskan teori-teori baru berkaitan dengan ilmu dakwah. Selain itu pentingnya penelusuran itu juga karena telah banyak teori yang mendahului lahir, sekaligus telah relatif mapan dalam konteks pengembangan ilmu-ilmu sosial.

Pemilihan ilmu sosial sebagai landasan pijakan pengembangan ilmu dakwah, didasarkan pada satu asumsi bahwa teori-teori dakwah yang hendak dibangun merupakan produk generalisasi dari fenomena sosial. Ilmu dakwah dengan sendirinya merupakan bagian dari ilmuilmu sosial, yang dirumuskan serta dikembangkan dengan mengikuti norma ilmiah dari ilmu-ilmu sosial. Misalnya teori-teori itu dirumuskan melalui pendekatan rasional, empiris dan sistematis.

Untuk membangun teori-teori dakwah, kita dapat melakukannya melalui kegiatan ilmiah yang dapat memberikan konsep dan generalisasi baru yang diangkat dari penemuan-penemuan ilmiah, atau fakta-fakta sosial yang berkembang. Jika kegiatan ini terus dilanjutkan, maka pada tahap-tahap tertentu akan ditemukan titik-titik pertemuan antara teori-teori sosial yang telah dulu lahir dengan kenyataankenyataan empiris baru yang ditemukan pada dataran kegiatan dakwah.

\section{B. Mabadi Ilmu Dakwah}

Ilmu dakwah sebagai salah satu bidang Ilmu Islam, berisikan teori dakwah, salah satu essensi teori dari segi tujuannya, adalah explanasi (bayan) tentang keapaan kajiannya, dan keapaan yang dikaji. Keapaan dakwah mengharuskan adanya 10 penjelasan pokok dalam tradisi ilmuan muslim dan hanya tiga dalam kajian filsafat Barat. Mabadi 'asrah (jamak dari 'mabda) yang artinya: asalnya, puncak mula terbit, dan sebab. Maksudnya ialah keterangan yang ringkas atau tujuan sesuatu ilmu sebelum membaca atau belajar ilmu itu. Kesepuluh mabadi tersebut yaitu: 


\section{1. al-Haddu (Batasan/Hakikat)}

Dari beberapa literatur para pakar telah mencoba merumuskan tentang definisi ilmu dakwah, antara lain Dr. Ahmad Ghalwasy dalam Ad Dakwah Al-Islamiyyah, Ilmu dakwah adalah ilmu yang dipakai untuk megetahui berbagai seni menyampaikan kandungan ajaran Islam, baik itu aqidah, syari'at maupun akhlaq. Hasil rumusan definisi Ilmu dakwah pada pertemuan para sarjana Fakultas Dakwah se-Jawa Tahun 1978 memeberikan kesimpulan bahwa ilmu dakwah: sebagai Ilmu yang mempelajari proses penyampaian ajaran agama Islam kepada umat; Ilmu yang mempelajari hubungan antara unsur-unsur dakwah; dan Ilmu pengetahuan yang mempelajari gejala penyampaian agama dan proses keagamaan dalam segala segi.

Dakwah sebagai aktivitas merupakan sesuatu yang telah muncul sejak adanya kenabian yang awalnya disampaikan oleh Rasulullah saw. Berbeda dengan ilmu dakwah, walaupun dakwah sudah inheren dengan gerak Islam sejak awalnya, namun tidak dengan ilmu dakwah. Ilmu dakwah bisa dikatakan ilmu yang relatif baru. Ilmu dakwah lahir belakangan jika dibandingkan dengan ilmu keislaman lainnya, seperti ulumul qur'an, ulumul hadits, dan lain sebagainya.

Ilmu dakwah sebenarnya lebih dekat ke arah ilmu komunikasi sosial. Oleh karenanya, ilmu dakwah dengan sendirinya merupakan bagian ilmu-ilmu sosial, yang dirumuskan dan dikembangkan dengan mengikuti norma ilmiah dari ilmu-ilmu social. Pada sisi lain, sebagai sebuah disiplin keilmuan, ilmu dakwah terus berkembang seiring dengan perkembangan ilmu, teknologi dan masyarakat. Ilmu dakwah mempunyai banyak cabang, diantaranya adalah: filsafat dakwah, sejarah dakwah, fiqhud dakwah, Rijalul dakwah, metodologi dakwah, manajemen dakwah, psikologi dakwah, perbandingan dakwah, sosiologi dakwah, dan sebagainya. Cabang-cabang atau struktur dari ilmu dakwah ini tidak akan pernah berhenti. Ilmu dakwah akan terus berkembang seiring dengan perkembangan waktu, ilmu dan teknologi.

Dalam hal ini, kelayakan ilmu dakwah sebagai suatu ilmu yang berdiri sendiri kini sudah menjadi suatu yang logis, dan tidak diragukan lagi sebagaimana sebelumnya sebab pada dasarnya, pembidangan ilmuilmu ke-Islaman telah lama dilakukan yang merupakan sistem keilmuan Islam. Secara umum, ilmu-ilmu yang berkembang dalam sejarah Islam 
meliputi ilmu al-Qur'an, ilmu hadits, ilmu tafsir, bahasa Arab, ilmu kalam atau teologi, fiqih siyasah atau hukum tata negara, peradilan, tasawuf, tarekat, akhlaq, sejarah politik, ilmu dakwah, sain Islam, pendidikan Islam, peradaban Islam, perbandingan agama, kebudayaan Islam, studi bahasa-bahasa dan sastra-sastra Islam, dan seterusnya. Ilmu-ilmu itu kemudian berlanjut berkembang dan memiliki cabang masing-masing (Nasution, 1989: 351, lihat juga Abdullah, 2002: 30-31).

\section{Maudhu' (Peta Kajian/ Pokok bahasan)}

Ilmu-ilmu itu dapat diklasifikasikan ke dalam matematika, fisika, kimia, astronomi, geologi, biologi dan ilmu-ilmu sosial, maka ilmu dakwah termasuk dalam kelompok ilmu-ilmu sosial" (Saby, 2000: 1). Pendapat ini tidaklah berlebihan jika ditinjau dari perkembangan pengklasifikasian ilmu pengetahuan sekarang ini, di mana pada umumnya, para ilmuwan membagi ilmu pengetahuan dalam tiga bidang, yaitu: (1) natural science (ilmu pengetahuan alami); (2) social science (ilmu pengetahuan sosial); dan (3) humaniora (ilmu pengetahuan budaya) (Tafsir, 2006: 25-27). Ilmu-ilmu sosial dinamakan demikian, oleh karena ilmu-ilmu tersebut mengambil masyarakat atau kehidupan bersama sebagai objek yang dipelajarinya, atau dengan kata lain yang menjadi objek material ilmu-ilmu sosial adalah masyarakat manusia yang selalu berubah-ubah (Soekanto, 1990: 12).

Berpijak dari pandangan di atas, berarti tidaklah berlebihan jika disebutkan bahwa setiap bidang ilmu-ilmu sosial-termasuk ilmu dakwahmempunyai objek material yang sama, yakni manusia. Sebaliknya masing-masing bidang sasarannya akan berbeda jika ditinjau dari sisi objek formalnya (sudut pandang). Sebagai ilustrasi tentang adanya perbedaan objek formal dalam ilmu-ilmu sosial ini, mungkin dapat diambil contoh berikut. Jika sekiranya yang termasuk dalam bidang ilmu-ilmu sosial, seperti ilmu ekonomi yang merumuskan teori berkaitan dengan segala kegiatan manusia yang beraspek pemenuhan kebutuhan materi manusia dalam proses-dari reproduksi sampai dengan konsumsi,--maka ilmu dakwah yaitu "ilmu yang ingin merumuskan serangkaian teori/tata cara tentang seruan yang berkaitan dengan keyakinan dan sikap seseorang atau sekelompok orang (yang 
telah diyakini kebenarannya) kepada orang atau kelompok lain yang dianggap belum sama persepsi" (Saby, 2000: 2).

Dengan kata lain, objek penelaahan ilmu dakwah adalah memiliki objek-objek material dan objek formal. Objek material ilmu dakwah sebagaimana ilmu-ilmu sejenis lainnya adalah tentang tingkah laku manusia. Sedangkan objek formalnya adalah usaha manusia untuk menyeru atau mengajak manusia lain dengan ajaran Islam agar menerima, meyakini, dan mengamalkan ajaran Islam bahkan memperjuangkannya". Dengan demikian, maka yang menjadi objek telaah ilmu dakwah adalah manusia dengan segala sikap tingkah lakunya yang berkaitan dengan aktifitas dakwah (Amin, 2008: 29-30).

\section{Ats-Tsamrah (Nilai Guna)}

Secara umum, nilai guna ilmu dakwah adalah mengembalikan manusia pada fitrahnya, dan manusia menjalani kehidupan bermasyarakat berdasarkan ajaran-ajaran islam, sehingga tercapai kehidupan yang damai dan harmonis.

Sedangkan secara teologis Qur'ani, yaitu: terselenggaranya upaya mendidik calon da'i profesional yang berkeunggulan kompetitif dengan basis kompetensi dakwah sebagai anggota individu umat terbaik (khair ummah) dengan karakteristik: (a) integritas individu (khairul bariyah); (b) berbekal keahlian dan keterampilan teoritik dan praktik (zadut taqwa); (c) innovator, pelopor dan problem solver dalam pembaharuan (khair al-fatihin); (d) mengambil keputusan yang objektif dan profesional (khair al-hakimin); (e) penata laksana keserasian lingkungan hidup (khair al-munzilin); (f) berorientasi ke masa depan (wa ladal al-akhirah khair); (g) berwawasan prospektif (khair amala); (h) pemilik reward (khair tsawaba dan khair uqba); (i) berperan dan berstatus kredibel (khair maqama); (j) pewaris universalitas nubuwwah dan risalah (khair waritsin); (k) kredibiltas kepribadian (al-qawi alamin); (l) berdaya kompetitif (sabiqun al-awwalun).

\section{Nisbah (Kaitan dengan Ilmu Lain)}

Secara umum ada dua paradigma yang memperngaruhi arah perkembangan ilmu dakwah. Dua paradigma tersebut adalah: (1) Bila 
ilmu dakwah hanya diletakkan pada kelompok paradigma logis normatif, maka ilmu dakwah harus dikembangkan sejalan dengan perkembangan ilmu-ilmu tradisional Islam. Karena ilmu dakwah ditarik dari al-Qur'an, maka ilmu tafsir menjadi sangat erat kaitannya. Karena ditarik dari hadits maka ilmu hadits menjadi sangat relevan. Dan karena sesekali menyangkut hukum Islam, ilmu fiqh dan ushul fiqh menjadi penting; (2) Bila ilmu dakwah mau dikaji secara empiris, maka ilmu dakwah harus diletakkan dalam kelompok ilmu-ilmu perilaku (behavior science) atau ilmu-ilmu sosial (social science). Walaupun begitu, ilmu dakwah erat kaitannya dengan ilmu komunikasi (Amin, 2008: 35).

\section{Fadl (Kepakaran/ Keutamaan)}

Keberadaan ilmu dakwah cukup dirasakan urgensinya dan mempunyai kedudukan yang sangat strategis. Keberadaan dakwah Islam disebut strategis karena pada tahap operasional, kegiatan dakwah-lah yang lebih dominan berperan dalam sosialisasi dan pelembagaan konsep-konsep Islam di tengah-tengah masyarakat. Karena itu, tanpa kegiatan dakwah, tentu upaya pengembangan dan pemasyarakatan sistem keilmuan Islam menjadi lamban.

\section{Wadhi' / Peletak dasar}

Pada awal abad ke-20 pemikiran dakwah mulai dirintis menjadi ilmu pengetahuan yaitu pada tahun 1912, di kairo tepatnya didirikanya sebuah lembaga yang bernama Dar al dakwah wa al irsad untuk menghalang gerakan kristenisasi. Lembaga ini kemudian ditutup karena terjadinya perang dunia ke II. Sejarah pemikiran dakwah sebagai suatu disiplin keilmuan, dimulai pada tahun 1918 di fakultas ushuluddin universitas Al-Azhar dengan pencetus gagasannya ialah Syaikh Ali Mahfudz dalam tulisannya mengenai "Al-Wa'dhu wa Al-Irsyad" dalam bukunya yang menjadi teks dakwah, Hidayat Al-Mursyidi fi Thuruq AlWa'dhi wa Al-Hidayah. Oleh karenanya, tahun 1918 diusulkan sebagai tahun lahirnya ilmu dakwah dan Hidayat Al-Mursyidin fi Thuruq AlWa'dhi wa Al-Hidayah dianggap sebagai kitab pertama dibidang dakwah.

Sedangkan di Indonesia sendiri pertama kali dakwah hanya berkembang di pesantren pesantren saja. Itupun bukan sebagai ilmu 
tapi melainkan menciptakan para dai. Dengan banyaknya para dai maka akan semakin banyak orang masuk Islam. Setelah masa itu ilmu dakwah mulai menjadi bahan diskusi ilmiah. Ilmu dakwah mulai menjadi ilmu yang diakui yaitu ketika perguruan tinggi agama islam negri (PTAIN) dibentuk pemerintah pada tanggal 26 september 1951, dimana dakwah menjadi salah satu jurusannya, selain jurusan tarbiyah dan jurusan Qadla.

\section{Isim (nama)}

Istilah-istilah yang berhubungan erat dengan Dakwah, antara lain:

a. Tabligh: Menyampaikan ajaran Islam kepada orang lain Pelakunya disebut: "Muballigh"

b. Khutbah: Berasal dari kata خطب yang artinya ; mengucapkan atau berpidato, pelakunya disebut " Khotib “. Menurut Abu Bakar Atceh Khutbah alah dakwah atau tabligh yang diucapkan dengan lisan padaupacara - upacara agama sepreti khutbah jum'at, khutbah hari raya, khutbah nikah dan lain lain yang memiliki corak syarat dan rukun tertentu.

c. Nashihah: Menyampaikan perkataan yang baik kepada seseorang atau beberapa orang untuk memperbaiki sikap dan tingkah lakunya, pelakunya disebut " نا صح"

d. Fatwa: Memberikan uraian atau keterangan agama mengenai suatu masalah, pelakunya disebut " Mufti “

e. Tabsyir/Targhib: Memberikan uraian keagamaan kepada orang lain yang isinya berupa berita menggembirakan orang yang menerimanya, pelakunya disebut " Mubassyir “

f. Tandzir/Tarhib: Menyampaikan ajaran Islam kepada orang lain yang isinya berupa berita peringatan atau ancaman bagi yang melanggar syari'at, pelakunya disebut " Mundzir “

\section{Istimdad / Dasar ilmu.}

Sumber ilmu dakwah adalah Al-Quran, al-Sunnah, serta produk Ijtihad. Al-Quran diyakini sebagai sumber segala ilmu dakwah. Dengan kata lain, Al-Quran dapat dikatakan sebagai kitab al-Da'wah, karena di 
dalamnya terdapat isyarat sekaligus syarat yang jelas mengenai apa, bagaimana, dan untuk apa kegunaan dakwah Islamiyah.

Asal usul ilmu-ilmu dakwah-itu berasal dari Allah SWT., yang kemudian memberi kekuatan dan kemampuan kepada manusia untuk mengetahuinya melalui beberapa sumber atau saluran, yaitu melalui wahyu, rasio dan indera. Sumber pengetahuan ilmu dakwah yang di dapat melalui wahyu, misalnya dapat diketahui dan ditemukan melalui ayat-ayat al-Qur'an, seperti dalam surat An Nahl: 125, Ali Imra: 104, 110, dan sebagainya. Bahkan menurut Muhammad Fuad Abdul Baqi, dalam al-Qur'an kata-kata dakwah dan kata-kata yang terbentuk darinya disebutkan tidak kurang dari 213 kali (Baqi, t.t.: 120). Suatu sebutan yang tidak sedikit berkaitan dengan perintah ajakan kepada ajaran Islam, dan tentunya semua ini menjadi sumber dari landasan pengembangan ilmu dakwah itu sendiri.

Adapun sumber-sumber pengetahuan dakwah yang ditemukan dalam hadits juga tidak sedikit, yang kesemuanya dapat dijadikan prinsip dan dapat dirumuskan menjadi dalil-dali aqli (rasio) lebih lanjut sebagai sumber yang kedua setelah wahyu (al-Qur'an dan hadits).. Sehubungan dengan penggunaan akal (rasio) sebagai sumber kedua keilmuan dakwah, dalam perkembangan sekarang ini para ilmuan Islam terkadang terhenti dan terjebak dalam suatu dilema ketika ingin membuktikan eksistensi sebuah ilmu, khususnya ilmu-ilmu ke-Islaman (tak terkecuali ilmu dakwah). Hal ini tidak lain adalah karena mereka dipengaruhi dan terjebak oleh perkembangan epistemologi yang berkembang di Barat yang sedikit banyak berbeda dengan epistemologi dalam pandangan Islam. Jika di Barat ilmu beranjak dari suatu premis kesangsian, maka dalam level wahyu, ilmu-ilmu ke-Islaman (seperti juga ilmu dakwah) bersumber pada premis keyakinan. Jadi berbalikan. Di sini pula pembicaraan secara akademik sering terhenti, lantaran sudah terkavling dengan wahyu tadi. Ilmuan Muslim sering terjebak oleh jerat sendiri bahwa ilmu-ilmu ke-Islaman identik dengan wahyu. Fiqh identik wahyu, ilmu kalam identik wahyu, tasawuf identik wahyu, ilmu dakwah identik dengan wahyu, dan seterusnya, sehingga dianggap sedikit banyak menghilangkan fungsi akal, akibatnya diskusi hanya berlari di tempat. 
Dalam Islam, munculnya ilmu-ilmu ke-Islaman seperti adanya ilmu dakwah adalah dalam rangka memahami wahyu untuk dipraktekkan. Wahyu yang di dalam wujudnya adalah al-Qur'an dan hadits yang shahih, yang dalam perspektif epistemologi Islam menjadi sumber utama ilmu-ilmu tersebut. Namun al-Qur'an atau katakanlah wahyu, sendiri adalah hudan, bukan proposisi, bukan buku undangundang (not a book of code), bukan teori, bukan hipotesa, bahkan juga bukan asumsi dalam kadarnya yang "ilmiah", yang berarti bisa diobrakabrik oleh manusia dengan kedok "ilmiah" pula.

Dengan cara berfikir demikian, ilmu-ilmu ke- Islaman tersebut maka dapat menjadi kajian ulang secara kritis. Oleh karena asal usul segala ilmu dari Allah, maka manusia hanya menjadi perumus teoriteori yang diangkat atau dirumuskan berdasarkan dinullah (wahyu Allah yang tertulis, yang terdapat dalam al-Qur'an dan al-Sunnah) atau Sunnatullah (hukum Allah yang diberlakukan pada alam semesta). Ketika merumuskan teori-teori dakwah berdasarkan dinullah dan sunnatullah itulah mereka menggunakan akal (penalaran). Di sinilah akal berfungsi melakukan perenungan, dan hasil yang dicapai tidak mutlak lagi, namun sudah merupakan hasil ijtihad sebagaimana di jelaskan di atas. Selain dari akal (rasio) sebagai sumber dari eksistensi ilmu dakwah, kekuatan indera (empiris) juga merupakan basis yang tak kalah pentingnya dalam merumuskan teori-teori ilmu dakwah. Melalui pengalaman empiris dan persepsi, yaitu dengan menggunakan observasi, eksperimen, laporan sejarah, deskripsi pengalaman kehidupan dan semacamnya. Pengetahuan yang dicapai melalui indera selalu di dasarkan pada pengamatan terhadap fakta-fakta dakwah secara empiris. Benar salahnya pengetahuan juga akan diukur dari pengamatan terhadap fakta-fakta atau kenyataan yang ada. Dengan demikian, dapatlah dipahami bahwa eksistensi ilmu dakwah dalam Islam berdasarkan intelek, yang mengarahkan rasio untuk membentuk ilmu yang bertumpang pada kesadaran dan keimanan terhadap kekuasaan Allah. Inilah ilmu yang menjadi petunjuk (hidayah) dari kegelapan menuju terang (nur) (Saefuddin, 1991: 35). Suatu ilmu yang mengemban misi kesejahteraan hidup manusia, dunia maupun akhirat. 


\section{Hukum}

Sebagaimana hukum dakwah, berdasarkan ayat al-Qur'an, mayaoritas ulama sepakat bahwa hukum dakwah itu secara umum adalah wajib, sedangkan yang menjadi perdebatan adalah apakah kewajiban itu dibebankan kepada individu muslim atau hanya dibebankan kepada kelompok orang saja dari secara keseluruhan, perbedaan pendapat mengenai hukum berdakwah disebabkan perbedaan cara pemahaman mereka terhadap dalil-dalil nakli disamping kenyataan kondisi setiap muslim yang berbeda pengetahuan dan kemampuan. Ayat yang menjadi pokok pangkal pendapat itu adalah surat Ali-Imran ayat 104. "Dan hendaklah ada di antara kamu segolongan umat yang menyeru kepada kebajikan, menyuruh kepada yang ma'ruf dan mencegah dari yang munkar, merekalah orang-orang yang beruntung".

Selain al-Quran, di dalam hadits juga terdapat perintah atau suruhan untuk melakukan dakwah. Hukum dakwah ini nampaknya juga akan berbeda pada setiap orang tergantung situasi dan kondisi yang dialami orang tersebut dalam pandangan hukum. Abu Sa'id Al-Khudry ra. Berkata, Aku Mendengar Rasulullah SAW., bersabda "Barangsiapa diantara kamu melihat kemungkaran, maka hendaklah ia mencegah dengan tangan (kekerasan atau kekuasaan), jika ia tidak sanggup dengan demikian (sebab tidak memiliki kekuatan dan kekuasaan), maka dengan lidahnya, dan jika tidak mampu (dengan lidahnya) yang demikian itu adalah selemah-lemah iman". (HR. Muslim).

Dengan demikian berdasarkan hadits tersebut menurut penulis ada dua macam hukum ilmu dakwah yaitu hukum secara umum dan hukum secara khusus. Hukum secara umum adalah mempelajari ilmu dakwah ditetapkan sebagai kewajiban yang hukumnya fardu kifayah. Sedangkan hukum secara khusus adalah ketetapan hukum yang dijatuhkan kepada seseorang yang keluar dari hukum fardu kifayah, disebabkan oleh tingkatan kemampuan dan ketidakmampuan seseorang.

\section{Masail (Permasalahan/Problematik)}

Secara umum masalah yang dikaji dalam ilmu dakwah adalah berbagai hal yang berkaitan dengan dakwah, sehingga dakwah dapat 
terlaksana dengan baik, efisien, dan berhasil. Berikut secara global masalah yang dikaji dalam ilmu dakwah:

a. Masalah hakikat dakwah dan pemahaman esensi Islam.

b. Masalah tabligh dan silaturrahim (komunikasi) Islam.

c. Masalah model prilaku Islam secara empiris (amal sholeh).

d. Masalah efisiensi dan efektivitas pencapaian sasaran dan tujuan dakwah.

e. Masalah sosialisasi, internalisasi, dan eksternalisasi ajaran Islam dengan menggunakan sarana mimbar dan media massa (cetak dan audio/visual).

f. Masalah bimbingan dan penyuluhan Islam ( $\left.t a^{\prime} d i b\right)$

g. masalah dan pemecahan problem psikologis dengan psikoterapi Kegiatan pengembangan masyarakat Islam

h. pengembangan masyarakat Islam terdiri dari kegiatan pokok : transformasi dan pelembagaan ajaran Islam ke realitas Islam.

i. Masalah manajemen dakwah

\section{Penutup}

Langkah penting yang dilakukan dalam rangka rivitalisasi Ilmu Dakwah adalah dengan menelusuri terlebih dahulu unsur ilmiah yang mungkin dapat dibangun. Dengan demikian, terdapat kerangka pikiran yang jelas dalam merumuskan teori-teori baru berkaitan dengan Ilmu Dakwah. Selain itu, penulusuran di atas juga sebagai penggalian terhadap banyak teori yang mendahului kelahiran ilmu dakwah, sekaligus telah relatif mapan dalam konteks pengembangan ilmu-ilmu sosial.

Kesuksesan realisasi revitalisasi pengembangan kelimuan dakwah Islam ditentukan oleh adanya partisipasi aktif, positif, produktif, dan inovatif semua pihak mukalaf dalam ilmu dakwah Islam.[] 


\section{DAFTAR PUSTAKA}

Azizy, A. Qodri. 2003. Pengembangan Ilmu-Ilmu Ke-Islaman, Jakarta: Departemen Agama RI - Direktorat Perguruan Tinggi Agama Islam

Saefuddin, A.M. et.al. 1991. Desekularisasi Pemikiran: Landasan Islamisasi. Bandung: Mizan

Abdullah, 2002. Wawasan Dakwah: Kajian Epistemologi, Konsepsi dan Aplikasi Dakwah, Medan: IAIN Press

Abu Musa, 1988. al-Qur'an wa al-Falsafah. terj. Ahmad Daudy, Jakarta: Bulan Bintang

Subandi, Ahmad. 1994. Ilmu Dakwah, Bandung: Syahida

Tafsir, Ahmad. 2006. Filsafat Ilmu: Mengurai Ontologi, Epistemologi dan Aksiologi Pengetahuan. Bandung: Remaja Rosdakarya

Ahmad, Amrullah. 1994. Sistem Pendidikan Fakultas Dakwah. Jakarta: Majalah Media Dakwah

Departemen Pendidikan Nasional. 2003. Kamus Besar Bahasa Indonesia. Jakarta: Balai Pustaka

Nasution, Harun. 1989, Islam Rasional: Gagasan dan Pemikiran. cet. I, Bandung: Mizan

Baqi, M. Fuad Abdul. t.t. Al-Mu'jam Al-Mufahras li Alfazh Al-Qur'an. Cairo: Dar Al Kutub Al-'Arabiyyah

Amin, Samsul Munir. 2008. Rekonstruksi Pemikiran Dakwah Islam. Jakarta: Amzah

Soekanto, Soerjono. 1990. Sosiologi Suatu Pengantar. Jakarta: Rajawali Pers

Saby, Yusny. 2000, "Epistemologi Ilmu Dakwah" dalam Ilmu Dakwah Ditinjau Dari Berbagai Aspeknya. Medan: Monora 